\title{
MYŚL PONAD GRANICAMI: INTERDYSCYPLINARNOŚĆ I INNOWACYJNOŚĆ TWÓRCZOŚCI GEORGA SIMMLA
}

\author{
Dariusz Brzeziński \\ Polska Akademia Nauk \\ University of Leeds
}

\section{/// Wprowadzenie}

Jednym z najważniejszych założeń teorii kultury (Simmel 2007a) i filozofii życia (tenże 2007b) Georga Simmla było twierdzenie, że: „Człowiek urodził się, żeby przekraczać granice" (tenże 2006: 337). Autor Filozofiipieniadza przekonywał, że istota bytu ludzkiego zawiera się w twórczym procesie relatywizowania istniejącej rzeczywistości i podejmowania prób mających na celu transformację przyjętych w niej rozwiązań instytucjonalnych, strukturalnych i aksjologicznych. Proces ten może wieść do wytworzenia nowych, innowacyjnych form, które są następnie włączane w materię życia, by stanowić punkt odniesienia do kolejnych przeobrażeń. Ergo, świat społeczny stanowi arenę nieustannych metamorfoz, zaś wszelkie granice, które się w jego ramach konstytuuja, sa jedynie tymczasowymi konstruktami, tyleż organizującymi sposób myślenia i działania jednostek, co skłaniającymi do ich przewartościowania. Simmel pisał w tym kontekście o złożonej, wzajemnej zależności między kondensacją ludzkiego doświadczenia w określone formy (Verdichtung) a twórczą aktywnością jednostek prowadzącą do zmian w świecie zewnętrznym (Kultivierung). 
Z powyższymi przekonaniami świetnie korespondował sposób, w jaki sam Simmel realizował się jako intelektualista. „Jego dzieło” - skonstatowała Dominika Motak (2013: 11) - „niemieszczące się w ramach żadnej z dziś już sprofilowanych dziedzin refleksji humanistycznej, współokreślało podstawy niejednej z nich". W istocie, cechą konstytutywną myśli Simmla było ,przekraczanie granic” między różnymi dziedzinami wiedzy: socjologia, filozofia, ekonomia, psychologia, kulturoznawstwem, literaturoznawstwem, historią sztuki etc. Prowadził on analizy par excellence interdyscyplinarne, a dzięki temu wytyczał nowe ścieżki myślowe. Kategoria, która w moim przekonaniu pozwala dobrze opisać jego stosunek do uprawiania refleksji naukowej, jest „intelektualista totalny”. Pojęcia tego używam za Pierre'em Bourdieu (2007: 321-326), który odnosił je do myśliciela dokonującego swobodnych transferów między różnymi polami twórczej aktywności. W niniejszym artykule przybliżę ową cechę twórczości Simmla, kładąc szczególny nacisk na to, w jaki sposób po dziś dzień stanowi ona inspirację dla badaczy reprezentujących nauki społeczne i humanistyczne. Swoje analizy podzielę na dwie części. W pierwszej podejmę refleksję nad kwestia ,przekraczania granic” w zakresie podejmowanych przez Simmla problemów badawczych. W drugiej skupię się na tym, jak z ową praktyką korespondował język jego wypowiedzi, stanowiący świetny przykład ,gatunku zmąconego" (Geertz 1996: 214-235). W podsumowaniu zinterpretuję jego sposób podejścia do pracy naukowej i jej odbiór przez współczesnych mu intelektualistów, przez pryzmat analiz, jakie zawarł on w swym słynnym eseju o „obcości” (Simmel 2005c: 204-212).

\section{/// Interdyscyplinarność twórczości Georga Simmla}

W datowanych na 9 grudzień 1912 roku słowach skierowanych do Marianne Weber Georg Simmel napisał: „Teraz przestawiam żagle i wyruszam na poszukiwanie lądu, na którym nie stanęła dotąd ludzka stopa. Ta podróż zakończy się prawdopodobnie jeszcze zanim dotrę do brzegu. Chciałbym tylko uniknąć losu wielu mi współczesnych, którzy tak zadomowili się na statku, że uznali, że właśnie on jest nowym lądem" (Gassen, Landmann 1958: 132) ${ }^{1}$. Słowa te można odczytywać jako jeden z kluczy do całej twórczości Simmla. Pochodzą one z jego dedykowanej Marianne Weber ksiazżki o Goethem (Simmel 1913), po której wydał on między innymi takie dzieła, jak: esej o Rembrandcie (tenże 1916, zob. też: tenże 2005b: 98-128), rozprawa o podstawach socjologii (tenże 1917), a także Filozofia

\footnotetext{
${ }^{1}$ Cytat ten podaję za książką Dominiki Motak i w jej tłumaczeniu: 2013: 31.
} 
życia (tenże 2007b). Rozległość tematyczna tych prac dowodzi niezwykłej wszechstronności jego zainteresowań badawczych. A stanowią one jedynie przykład tego, jak bardzo zróżnicowana, wyłamująca się poza wszelkie podziały dyscyplinowe była jego twórczość. W zbiorze jego dzieł obejmującym dwadzieścia cztery tomy - którego wydawanie zakończyła kilka lat temu oficyna Suhrkamp - znajdują się tyleż teksty wpisujące się swą formą w dyskurs naukowy, ile eseje pisane dla szerokiej publiczności; tak pisma przedstawiające rozpoznania metafizyczne, jak artykuły poświęcone analizom życia codziennego; zarówno prace koncentrujące się na polityce i ekonomii, jak i analizy dzieł literackich, malarskich czy architektonicznych. Spojrzenie z tej perspektywy na twórczość Simmla pozwala krytycznie odnieść się do wszelkich prób określania go mianem „socjologa” lub „filozofa”. Był on raczej ,intelektualistą totalnym”.

Wszystko to nie oznacza jednak, by nie próbować doszukiwać się w jego dziele pewnych prawidłowości, zarówno jeśli chodzi o jej ewolucję, jak i podejmowana problematykę. Tak on sam w swej „,niedokończonej autoprezentacji”' (tenże 1958: 9-10), jak jego pierwszy biograf, Max Frischeisen-Köhler (1919), a za nimi część komentatorów jego twórczości (zob. Motak 2013: 27-29), podzieliło ją na trzy zasadnicze fazy. W swych wczesnych pracach, inspirowanych myślą Kanta i Spencera, Simmel zajmował się on głównie studiami nad epistemologia, a także prowadził analizy z pogranicza historii i socjologii. Zwrot w jego twórczości znamionowało wydanie w 1900 jego opus magnum, to jest Filozofii pieniqdza (Simmel 1997). Od tego czasu skupiał się głównie na analizach społeczeństwa nowoczesnego, a także rozpoznaniach socjologicznych podejmowanych w ramach przyjętej przez niego definicji tej dyscypliny. Swą najważniejszą pracę poświęconą tej problematyce wydał w roku 1908 (tenże 2005c), która uważana jest za kolejną cezurę w jego twórczości. Od tego czasu Simmel pisał głównie dzieła z zakresu filozofii kultury, estetyki, a także - choć może przede wszystkim - filozofii życia (tenże 2007b). Mając na uwadze stosowana przez niego samego nomenklaturę, okres ów nazywany jest „metafizycznym” (tenże 1958: 9). Trzeba jednak w tym miejscu zaznaczyć, że choć przywołana tu periodyzacja unaocznia główne kierunki ewolucji myśli Simmla, to nie zdaje sprawy ze skomplikowanych zależności między kolejnymi jej etapami. Nie uwzględnia na przykład tego, że tematy socjologiczne sensu stricto były przez niego eksplorowane do końca pracy naukowej, a próby filozoficznego ujęcia bytu ludzkiego pojawiały się w jego twórczości już na przełomie XIX i XX wieku. 
Niezależnie od kolejnych stadiów ewolucji myśli autora Filozofii pieniq$d z a$ był jednak jeden wątek, który stale cieszył się jego zainteresowaniem. Badacze twórczości Simmla jednomyślnie wskazują tu na problematykę kultury, której poświęcił zarówno liczne studia teoretyczne, jak i analizy zogniskowane na jej poszczególnych fenomenach (zob. Frisby, Featherstone 1997; Magala 1980: 50-79). Sławomir Magala napisał w tym kontekście: „Simmel nie był jedynym myślicielem, który punktem centralnym filozofii uczynił koncepcję kultury, ale należał do dosyć wąskiego grona twórców usiłujących wyjaśniać osobliwości odwiecznych pytań w filozofii opisem mechanizmu i funkcjonowania kultury, świata «zobiektywizowanych form»" (1980: 50-51). Można skonstatować, że problematyka kultury była swego rodzaju zwornikiem zespalającym rozproszone zainteresowania autora Filozofii mody, ale jednocześnie nie krępującym bynajmniej ich swobodnego rozwoju. To w jej perspektywie analizował on relacje między światem natury a światem człowieka, kreatywnościa jednostki a istnieniem „zobiektywizowanych form”, kondycją tradycyjną a nowoczesną etc. Co więcej, rozważania Simmla poświęcone tak istocie, jak ówczesnym przemianom kultury nadawały ogólny kierunek innym prowadzonym przez niego analizom. Na przykład podkreślanie jej procesualnego charakteru ${ }^{2}$ (Simmel 2007a) korespondowało z przypisywana przez niego jednostce zdolnością do transcendowania istniejącej rzeczywistości (Simmel 2007b). Z kolei analizy dotyczące heterogeniczności kultury znalazły odzwierciedlenie w pracach, w których ukazywał rosnąca dynamikę świata nowoczesnego. Taki sposób ukierunkowania jego myśli jest uznawany za prekursorski względem późniejszych przeobrażeń w naukach społecznych i humanistycznych (Brzeziński 2019: 119-136; De La Fuente 2016: 78-90; Frisby 1992: 155-174).

Aspektem kultury, który szczególnie interesował Simmla, były jej symboliczne reprezentacje ${ }^{3}$. W swych tekstach wielokrotnie poddawał on analizie zarówno konkretne utwory artystyczne, jak i działalność poszczególnych twórców czy też panujące w danej epoce tendencje estetyczne. Jednym z pierwszych efektów jego zainteresowania sztuką była - odrzucona z przyczyn formalnych - praca doktorska o psychologii i etnologii muzyki (Simmel 1882: 261-305; zob. Etzkorn 1964: 101-107). Chociaż nie

\footnotetext{
${ }^{2}$ Ów sposób teoretyzowania kultury był istotna inspiracją np. dla jej „czasownikowego” ujęcia przez Ryszarda Nycza (2017) czy też spojrzenia na nią przez pryzmat kategorii praxis przez Zygmunta Baumana (2012).

${ }^{3}$ W drugiej połowie roku 2020 University of Chicago Press wyda pod redakcją Austina Harringtona książkę pod tytułem Georg Simmel: Essays on Art and Aesthetics, zawierająca ponad czterdzieści esejów autora Filozofii pieniadza, poświęconych sztuce, estetyce i różnym zjawiskom artystycznym.
} 
pociagnęła ona za sobą kolejnych pogłębionych studiów poświęconych tej problematyce, to do dziś pozostaje ważna jako dzieło, które w znaczący sposób przyczyniło się do wyznaczenia pola zainteresowań subdyscypliny, jaka jest socjologia muzyki (Jabłońska 2014: 84-87). W kolejnych latach Simmel pisał na temat literatury (1913), malarstwa (1916, 2016: 9-19, 149155, 2005a: 89-97), rzeźby (2006: 94-105), architektury (tamże: 163-168, 177-183), sztuki aktorskiej (tamże: 213-219), a także - ogólnie - estetyki (tamże: 32-52). W pracach tych płynnie łączył rozważania z zakresu sztuki z refleksjami poświęconymi kondycji człowieka, analizami metamorfoz, jakim ulegała ówczesna kondycja, a także rozpoznaniami dotyczącymi podstawowych kategorii filozoficznych. I tak na przykład przywoływana już powyżej książka poświęcona Rembrandtowi (Simmel 1916) stanowi tyleż interpretację jego malarstwa, co zapis refleksji poświęconych relacji między życiem a „,formą”, w jakiej się ono realizuje. Z kolei eseje poświęcone architekturze Wenecji i Florencji (tenże 2006: 163-168, 177-183) są de facto także zbiorem rozważań na temat iluzji i prawdy czy też wieloznaczności i jednorodności ${ }^{4}$. Można z przekonaniem stwierdzić, że Simmel patrzył na dzieło artystyczne $z$ szerszej perspektywy swych filozoficznych, socjologicznych i kulturoznawczych rozważań. Z drugiej jednakowoż strony to właśnie sztuka dawała mu przystęp do łączenia rożnych porządków i transcendowania wyznaczonych granic. Pisał: „Sztuka - i na tym w ogóle polega jej sens i szczęście - ujawnia, że szeregi zjawisk, które w świecie rzeczywistym przebiegają obok siebie przypadkowo, obojętne sobie lub wrogie, łączy głęboka więź, że są ze sobą zestrojone [...]” (tamże: 151).

Konstatacja ta stanowi w moim przekonaniu dobry wstęp do wskazania dwóch charakterystycznych dla Simmla sposobów prowadzania analiz. Po pierwsze, przystępując do badań danego fenomenu, starał się zwykle ujać go w całej mnogości różnorodnych - niezależnych od wyznaczonych przez granice dyscyplin - kontekstów. Niech za przykład posłuży tu jego opus magnum. Punktem wyjścia do prowadzonych w nim analiz uczynił on przekonanie, że pieniądz nie stanowi wyłącznie środka wymiany. Wręcz przeciwnie - jak dowodził - „[...] można przyrównać go do krwi, której stały obieg uruchamia wszystkie członki i odżywiając je wszystkie jednakowo, powoduje jedność ich funkcji” (1997: 443). Przyjęcie takiej optyki stało u podstaw zespolenia analiz ekonomicznych z socjologicznymi, kul-

\footnotetext{
${ }^{4}$ Florencja w analizach Simmla jawiła się jako miasto charakteryzujące się harmonijna jednością, co pozostawało w kontrze do obserwowanego przez niego rozwoju fragmentaryzacji, polisemizacji czy też wręcz „symulakryzacji” kultury; te ostatnie tendencje omawiał na przykładzie architektury weneckiej.
} 
turoznawczymi, filozoficznymi etc. Dzięki wielokontekstowym refleksjom Simmel ukazał nie tylko bogactwo i złożoność przemian związanych $z$ upowszechnianiem się tytułowego środka płatniczego, ale także - a może przede wszystkim - nakreślił w całej feerii barw obraz konstytuującej się kondycji nowoczesnej. Odniósł się do ewolucji procesu uwarstwienia, wyłaniania się nowego typu indywidualizmu, fundamentalnych przemian aksjologicznych, rosnącej dynamiki życia społecznego etc. Filozofia pieniqdża jest przeto dziełem „,totalnym”. Jako takie po dziś dzień stanowi źródło inspiracji dla wszelakich analiz relacji między gospodarka, kultura i życiem społecznym (zob.: Karalus 2018: 429-445; Kuźniar 2018: 447-461; Markowska 2018: 485-498; Harrington, Kemple 2012: 7-25). A choć praca ta ma w dorobku Simmla znaczenie szczególne, to charakter prowadzonego w niej interdyscyplinarnego dyskursu jest obecny także w innych jego dziełach. Stanowi to de facto ich signum specificum.

Po drugie, dążenie do scalenia różnych porządków doprowadziło go do wyznaczenia nowych dróg rozwoju w naukach społecznych i humanistycznych. Simmel jest na przykład uważany za jednego z prekursorów socjologii zmysłów ${ }^{5}$ (Simmel 2006: 184-230; Vanini, Waskul, Gottschalk 2011). Dostrzegłszy potrzebę otwarcia refleksji społecznej na ten obszar, napisał: „Chcemy prześledzić, jakie znaczenie dla współżycia ludzi - dla tego, co ich łączy, sprzęga, różni - ma sposób, w jaki wzajemnie się postrzegają i wpływają na siebie za pośrednictwem zmysłów" (2006: 186). W zakres swoich analiz włączył on też - jako jeden z pierwszych - problematykę emocji (Shilling 2002: 10-32). Eksplorował ja zarówno w swych rozpoznaniach z zakresu socjologii formalnej (Simmel 2005c: 239-243), jak i w pracach poświęconych przekształceniom nowoczesności (tenże 2006: 114-134). Innym przykładem innowacyjnych ścieżek, którymi podążała jego myśli, była problematyka jedzenia (tamże: 272-282, zob. Symons 1994: 333-351). W poświęconym jej tekście pisał: „Wspólny posiłek wynosi zdarzenie fizjologicznie prymitywne i nieuchronnie powszechne w sferę wzajemnych oddziaływań społecznych i nadaje mu ponadosobistą range” (2006: 274). Świat życia był dla Simmla przedmiotem nieskrępowanej refleksji, jako że wszelkie jego przejawy wydawały mu się godne naukowych analiz. W ten sposób utorował on drogę do takich orientacji, jak choćby zwroty: „,sen-

\footnotetext{
${ }^{5}$ Beata Hoffmann (2019: 139) pisała w tej materii o Simmlu następująco: „Zwracając uwagę na rolę sensoryki w konstruowaniu rzeczywistości społecznej, stworzył podstawy dla rozwoju wąskiej specjalizacji zwanej socjologia zmysłów [...]. Dzięki pionierskiemu w socjologii podejściu do zmysłów jako bytów społecznych, a nie jedynie fizjologicznych, Simmel zmienił nie tylko perspektywę postrzegania zjawisk zmysłowych, ale zwrócił także uwagę na istotę poznania wielozmysłowego, jak i relacje zachodzące między zmysłami”.
} 
soryczny”, „afektywny” i „korporalny” (Bachmann-Medick 2012) czy też socjologia codzienności (Sztompka, Bogunia-Borowska 2008).

W podsumowaniu tej części artykułu chciałbym odnieść się do faktu, że twórczość Simmla przeżywa dziś swoisty renesans. Zwykle fenomen ten łączy się z faktem jego niezwykle trafnych rozpoznań poświęconych ewolucji kondycji nowoczesnej. Jest on jednak też pochodna postulowanego przez niego prekursorskiego modelu uprawiania nauki, zakładającego „przekraczanie granic” między dziedzinami i dyscyplinami. Powyżej starałem się unaocznić to, że wiele poszukiwań badawczych Simmla jest kontynuowanych i rozwijanych w ramach powstających subdyscyplin czy też orientacji. Dalsza wnikliwa lektura jego tekstów może stać się inspiracją dla kolejnych przewartościowań w naukach społecznych i humanistycznych.

\section{/// Język tekstów Simmla jako „gatunek zmącony”}

Tak wyłamujący się ze schematów sposób prowadzenia analiz przez Simm$1 a^{6}$, jak język, którym się posługiwał w większości swych dzieł, były przyjmowane przez wielu współczesnych mu intelektualistów co najmniej z rezerwą (zob. Coser 1958: 635-641; Cieśla 1993: 31-34). Zarzucano mu między innymi to, że zamiast rzeczowego i systematycznego wykładu swych poglądów często przedstawiał je w niepoddającej się regułom naukowości formie eseju. Negatywnie odnoszono się do jego metaforycznego, a zarazem aforystycznego stylu wypowiedzi, uznając go za bliższy formom literackim niż dyskursowi akademickiemu. W końcu też nierzadko bez uznania wypowiadano się o tym, że w wielu swych pracach otwierał jedynie przestrzeń do dyskusji, zamiast udzielać konkluzywnych odpowiedzi . „Współcześni Georgowi Simmlowi” - pisał Lewis Coser (1958: 635) - „często zwracali uwagę na osobliwości stylu jego pracy, osobliwości, które w znaczący sposób wyróżniały go spośród wszystkich innych najważniejszych socjologów. Doceniali olśniewającą błyskotliwość jego pism i ich subtelna elegancję, ale podkreślali także brak systematyczności wywodu i niemalże wystudiowany nieład stosowanej przez niego metody". W niniejszej części

\footnotetext{
${ }^{6}$ Przez niemal trzy dekady Simmel wykładał bez stałego uposażenia na Uniwersytecie w Berlinie, najpierw jako Privatdozent, a następnie w randze profesora nadzwyczajnego. Dopiero w roku 1914, na cztery lata przed swą śmiercią, uzyskał stanowisko profesora zwyczajnego na Uniwersytecie w Strasburgu.

${ }^{7}$ Ernst Bloch wypowiedział się o Simmlu w Duchu utopii następująco: ,Jest kolekcjonerem punktów widzenia, które zbiera wokół prawdy, nigdy nie chcąc ani nie będąc w stanie jej posiąść. Spala się w krótkotrwałych i przypadkowych zapałach i przeważnie olśniewa błyskotliwymi pirotechnicznymi pokazami metodologii, które nas szybko nudzą" (Bloch 1918: 246; słowa te przytaczam w tłumaczeniu Sławomira Magali (1980: 115)).
} 
tekstu odniosę się do wzmiankowanych tu uwag, podkreślając, że stosowany przez Simmla język opisu w pełni korespondował z zadaniami, jakie przypisywał on intelektualiście. A był to - jak już wcześniej wskazywałem - wzorzec ,intelektualisty totalnego”. Charakterystyczny dla Simmla dyskurs - przełamujący granice między naukami społecznymi, humanistyką i sztuką - ujmę jako egzemplifikację Geertzowskiego „gatunku zmąconego" (Geertz 1996: 214-235).

Rozpoznania poświęcone tej problematyce warto rozpocząc od unaocznienia, że Simmel obracał się tyleż w kręgach towarzyskich intelektualistów, co pisarzy i artystów. Z częścią z nich - między innymi Rainerem Marią Rilkem, Auguste'em Rodinem i Stefanem Georgem - nawiązał także przyjaźnie (zob. Magala 1980: 11-12). Co więcej, sam podejmował próby literackie, które publikował w promującym secesję monachijskim czasopiśmie $J_{u g e n d}{ }^{8}$. Analizująca ten aspekt jego dzieła Monika Tokarzewska (2005: 131-132) napisała, że:

[...] twórczość literacka Simmla nie była po prostu hobby uprawianym w chwilach wolnych od pracy stricte naukowej (tj. socjologicznej i filozoficznej), ale refleksja pozwalająca mu dostrzec i przemyśleć wiele rzeczy, o których pisał także jako filozof i socjolog. Również niebagatelną rolę musiały one odegrać dla wykształcenia się stylu i języka Simmla.

Wpływy literackich i artystycznych inklinacji Simmla na tworzone przez niego teksty naukowe sa w istocie niezaprzeczalne. Znajduja odzwierciedlenie w posługiwaniu się przez niego poetyckim obrazowaniem, w stosowaniu kunsztownych porównań i metafor, a także w samym fakcie częstego wybierania przez niego formy wypowiedzi, jaką jest esej. Jerzy Szacki stwierdził: ,[...] w nauce, która [Simmel] uprawiał, widział przedsięwzięcie par excellence estetyczne i pisał wprost o przydatności kategorii estetycznych do opisu społeczeństwa” (2003: 448). Wolf Lepenies wskazywał natomiast, że Simmel: „[...] z satysfakcja przyjmował do wiadomości interpretacje swoich prac jako dzieł sztuki” (1997: 338).

Daleki od akademickości charakter większości tekstów Simmla wynikał jednak nie tylko z dowartościowania przez niego poetyckiej funkcji ję-

\footnotetext{
${ }^{8}$ Teksty literackie Simmla publikowane były anonimowo i sygnowane jego inicjałami. Zostały one zebrane i wydane pod jego nazwiskiem dopiero w roku 1998 (Simmel 1998). Znalazły się one także w siedemnastym tomie jego dzieł zebranych. Zob. Tokarzewska 2005: 131-146.
} 
zyka. Miał także ścisły związek z denotatywnym wymiarem tegoż (Jacobson 1989). Zygmunt Bauman wypowiedział się na ten temat następująco:

[...] rzeczywistość ukazywała się w pismach Simmla jako zbiór odłamków życia i okruchów informacji [...]. Dziś widać, że ,pokawałkowane" analizy Simmla przykrojone były na miarę kondycji ludzkiej, której Simmel, w odróżnieniu od wielu kolegów, domyślał się za fasadą całościujących ambicji administratorów, tej kondycji, która dziś wyłoniła się spod gruzów niespełnionych marzeń inżynieryjnych w całej swej rozchełstanej, fragmentarycznej, epizodycznej prawdzie - i została za taką uznana. [...] Chwałę przyznano Simmlowi pośmiertnie, gdy doświadczenie powszechne doszlusowało do jego intuicji (1995: 33).

W istocie, charakterystyczny dla Simmla dyskurs był nie tylko narzędziem opisu, lecz także środkiem, poprzez który ów starał się oddać istotę ówczesnej kondycji. Warto tu podać kilka przykładów. Otóż posługiwanie się przez niego techniką pisarska przypominająca „strumień świadomości” (Motak 2013: 20) korespondowało z rosnącą dynamiką przemian ówczesnego świata (Simmel 2006: 114-134). Zestawianie ze sobą w jednym tekście rozpoznań odnoszących się do różnych problematyk - przyrównane przez Monikę Tokarzewską (2008: 71) do artystycznej techniki montażu współgrało z procesem heterogenizacji rzeczywistości społecznej, a także z konstytuowaniem się nowej formy indywidualizmu (Simmel 2007a: 163177). Z kolei częste sięganie przez niego po formę eseistyczną można interpretować jako przejaw trudności ze scaleniem zachodzących ówcześnie przekształceń w jeden, spójny obraz? . Wszystkie te techniki konstruowania tekstu wspólprzyczyniły się do stworzenia wyjątkowo innowacyjnej wizji nowoczesności jako kondycji, w której liminalność przestała być stanem przejściowym, a zyskała status permanentnej, a jednocześnie też nadrzędnej własności życia społecznego.

Warto do tego dodać, że zakładanym odbiorcą większości tekstów Simmla nie mieli być bynajmniej akademicy, ale szersza publiczność. Analizujący ten aspekt jego twórczości Lewis Coser (1958: 635-641) zwrócił

\footnotetext{
${ }^{9}$ Odnosząc się do stylu Simmla Jerzy Szacki (2003: 449) napisał: „Najważniejsze wydaje się [...] w tym kontekście obsesyjne wręcz przekonanie Simmla, iż rzeczywistość jest nieskończenie zmienna i kalejdoskopowa, i nieuchwytna inaczej niż we fragmentach. W rozsypce jest zarówno współczesne społeczeństwo, jak i osobowość jednostki. Stąd zresztą, jak się zdaje, zauroczenie Simmla sztuką jako taką szczególną dziedziną, w której poprzez kontemplację szczegółu osiąga się coś w rodzaju oglądu całości, nieuchwytnej w żaden inny sposób”.
} 
uwagę na ciekawą zależność. Stwierdził, że do końca XIX wieku autor Filozofii ¿̇ycia publikował zarówno w czasopismach naukowych, w periodykach o profilu literackim i artystycznym, jak i w prasie popularnej. Z kolei po roku 1900 dominują w jego twórczości teksty pisane dla czasopism nieakademickich. Coser tłumaczył to faktem przeciągającego się oczekiwania na osiągnięcie profesury zwyczajnej, które - gdy się nie ziściło ${ }^{10}$ - wzbudziło w nim pragnienie, by znaleźć większe uznanie pośród szerszych kręgów czytelników. Odnosząc się do tych analiz, Stanisław Cieśla (1993: 32, 33) zauważył, że nie uwzględniają one pisanych przez Simmla książek, z których wiele miało w XX wieku charakter par excellence naukowy. Godzi się też zwrócić uwagę na to, że po 1900 roku kilkakrotnie ponawiał on próbę uzyskania profesury, co udało mu się dopiero cztery lata przed śmiercią. Bezsprzeczne jest natomiast to, że niezależnie od etapu swej pracy naukowej starał się on docierać do jak najszerszego grona odbiorców. Sprzyjało temu zarówno unikanie stosowania żargonu naukowego, jak i posługiwanie się licznymi odwołaniami do motywów, zagadnień i testów kultury stanowiących fundament społecznego imaginarium.

Wśród myślicieli, którzy w takim w sposobie konstruowania dyskursu inspirowali się pracami Simmla, był Zygmunt Bauman (1995: 19-44). ${ }^{11}$ Podobieństw tych jest jednak dużo więcej, gdyż dotyczą one zarówno wzmiankowanej wcześniej - denotatywnej funkcji języka ${ }^{12}$, jak i jego konatywnego wymiaru (Jacobson 1989). Autor Plynnej nowoczesności obrazowo ukazał swoje podejście do tej ostatniej kwestii przez unaocznienie zbieżności między zadaniami poetów i socjologów (Bauman 2006: 313-334). Przedstawiciele obu profesji powinni w jego przekonaniu dążyć nie tylko do opisywania rzeczywistości, ale także do jej relatywizowania. Poprzez uprzystępnianie jej konstruktywistycznego wymiaru mieliby oni otwierać

\footnotetext{
${ }^{10}$ W roku 1900 Simmel uzyskał nominację na profesora nadzwyczajnego. Choć pozwalało mu to na prowadzenie zajęć na uniwersytecie, to nie wiązało się bynajmniej z zajmowaniem znaczącej pozycji w jego strukturach.

${ }_{11}$ Bauman skonstatował „Popularny' język to tyle, co język zrozumiały dla 'niewtajemniczonych' a więc dla tych właśnie, dla których pożytku uprawia się - warto uprawiać - myślenie socjologiczne; i wobec których ponosi się odpowiedzialność za słowo" (Bauman, Kubicki i Zeidler-Janiszewska 2009: 25). Teksty pisane językiem egzoterycznym są charakterystyczne zwłaszcza dla publikacji Baumana pisanych po jego przejściu na emeryturę, choć w istocie pisał je przez całą swoją twórczość (zob. Palmer, Brzeziński, Campbell 2020: 118-133).

12 Bardzo podobnie do Simmla - i w znaczącej mierze w ślad za jego przykładem - Bauman posługiwał się takimi środkami retorycznymi, jak metaforyzacja, hiperbolizacja oraz poetyzacja dyskursu. Jednym z celów stosowania takich zabiegów było oddanie istoty przemian zachodzących w ramach społeczeństwa płynnonowoczesnego. W książce Razem osobno Bauman skonstatował (2005: 6): „Mogę liczyć najwyżej na portretową składankę, niejednorodny obraz zawierający równie wiele luk i miejsc pustych, co wypełnionych kolorem fragmentów. Lecz nawet tak pomyślana kompozycja będzie nie dokończonym zadaniem, które dopełnić mogą jedynie czytelnicy”.
} 
drogę do transcendowania zastanego porządku. Bauman stwierdził (tamże: 314): ,[...] powinniśmy podchodzić do ukrytych możliwości tak blisko, jak to czynia prawdziwi poeci. Dlatego winniśmy przebijać się przez mur oczywistości i zrozumiałego-samo-przez-się, tej obowiązującej ideologicznej mody, której powszechność ma dowodzić słuszności”. Gest przekroczenia był także dla Simmla konstytutywną cechą twórczości, tak artystycznej, jak naukowej. On sam, podobnie jak Bauman, wykorzystywał cała gamę środków literackich, by odwoływać się do wyobraźni czytelników, skłaniać ich do refleksyjnego oglądu rzeczywistości, a także motywować do poszukiwania innowacyjnych ścieżek myślenia i działania. Przy tym wszystkim sam rzadko przedstawiał gotowe rozwiązania; zdecydowanie częściej uruchamiał jedynie proces wiodący do przezwyciężania zaistniałych form. Wpisywało się to w jego wizję „filozofii życia”, której istotą była wzajemna, dynamiczna relacja między istniejącym a wyobrażonym czy też między bytem a powinnością (Simmel 2007b, zob. Gadacz 2005: 5-30).

Godzi się tu podkreślić, że w omawianym zakresie twórczość Simmla nie wpisywała się w pełni w istotę pojęcia „intelektualisty totalnego” w znaczeniu, jakie nadał mu Bourdieu (2007: 321-326). Autor Dystynkcji powiązał co prawda tę kategorię z zaangażowaniem, ale przekonywał też, że właściwe jest dla niej dążenie do osiagania konkretnych, jasno określonych celów. Sam Bourdieu wybrał opozycyjny model intelektualisty publicznego, to jest zachęcającego do dokonywania przewartościowań w świecie społecznym i dostarczającego narzędzi konceptualnych do prowadzenia aktywności politycznej (zob. Swartz 1997). Simmel zają w tej materii nieco inne stanowisko, które w moim przekonaniu można powiązać z rozwijanymi współcześnie nurtami w ramach myśli utopijnej, reprezentowanymi między innymi przez Ruth Levitas (2001: 25-43), Lymana Towera Sargenta (2006: 11-17) czy Russella Jacoby'ego (2005). Stworzone przez nich wizje opierają się na relatywizowaniu istniejącej rzeczywistości i zachęcaniu do kształtowania wizji alternatywistycznych, przy czym - co istotne - mają niefinalistyczny, procesualny charakter. Intelektualiści ci podobnie jak wcześniej czynił to Simmel - nie koncentrują się na przedkładaniu, popieraniu lub sekundowaniu w tworzeniu konkretnych rozwiązań, ale wskazują na potrzebę ciągłego wykraczania poza status quo.

Zamykając tę część tekstu, chciałbym odwołać się do spostrzeżeń Clifforda Geertza dotyczących przyczyn upowszechnienia się w naukach społecznych ,gatunku zmąconego”. Twierdził on, że wynikało to przede wszystkim ze zmian, jakie nastapiły w sposobie podejścia do analizy rzeczywistości społecznej. Ich istotą było porzucenie przez część badaczy 
wyjaśnienia w kategoriach nomologicznych na rzecz niekończącego się wysiłku interpretacyjnego. „Uwolnieni od obowiązku taksonomicznej nieskazitelności, jako że nikt już obowiązkowi temu sprostać nie zdoła" - pisał Geertz (1996: 217) - „uczeni uważający się za przynależnych naukom społecznym (lub behawioralnym, humanistycznym czy kulturowym) uzyskali swobodę $\mathrm{w}$ formowaniu swych zadań zgodnie $\mathrm{z}$ koniecznością wewnętrzną, nie zaś w myśl panujących koncepcji na temat tego, co powinien, a czego nie powinien robić badacz”. Kilka dekad przed napisaniem tych słów Simmel przyjął bardzo podobne założenie. Sposób, w jaki kształtował swój dyskurs na przełomie XIX i XX wieku, zdecydowanie wyprzedził swój czas, pozostając jednocześnie inspiracją dla współczesnych sposobów pisania o rzeczywistości.

\section{/// Zakończenie}

Simmel zyskał w trakcie swego życia uznanie po obu stronach Atlantyku, a także popularność wśród studentów, tłumnie zapisujących się na jego wykłady. Znaczna cześć intelektualistów była jednak co najmniej sceptyczna względem realizowanego przez niego modelu ,intelektualisty totalnego”. Zarówno sposób, w jaki prowadził swe analizy, jak i język, którym się posługiwał w swych tekstach, uznawali za „nienaukowe”. Wielu z nich podkreślało jednak trafność jego spostrzeżeń i nowatorstwo pisanych przez niego prac (zob. Magala 1980: 115-125). Ów pełen ambiwalencji stosunek do twórczości Simmla jest dobrze widoczny w napisanej w 1908 roku - acz nigdy nie opublikowanej ${ }^{13}$ - opinii, jaką sporządził o nim w 1908 roku Max Weber. Skonstatował w niej: „Chodzi zwłaszcza o to, że podstawowych aspektów jego metodologii zaaprobować nie sposób. Wyniki konkretnych analiz należy nader często traktować z zastrzeżeniami, a nierzadko odrzucać w całości. Co więcej, sposób prezentacji uderza nas czasem jako dziwaczny, a często jest niezrozumiały. Z drugiej strony, czujemy się zmuszeni przyznać, że taki sposób przekazywania materiału jest po prostu błyskotliwy, a co więcej prowadzi do wyników spójnych i oryginalnych, niemożliwych do osiągnięcia przez żadnego naśladowcę" (Levine 1971: XLV-XLVI).

Opinia ta świetnie oddaje moim zdaniem istotę kategorii „obcości”, zgodnie z zaproponowanym przez Simmla sposobem rozumienia tego

\footnotetext{
${ }^{13}$ Opinia ta przechowywana jest w Instytucie Maxa Webera w Monachium. Przytaczam ją tu w tłumaczeniu Sławomira Magali, który zawarł jej obszerne fragmenty w swej monografii poświęconej Simmlowi (1980: 118).
} 
pojęcia (Simmel 2005c: 300-304). Warto tu przypomnieć, że kategorię tę odnosił on do sytuacji jednoczesnego przypisywania członkowi grupy przeciwstawnych własności. „Obcy” jest zarówno „daleki”, jak i „bliski”, darzony uznaniem, a zarazem nie traktowany jako pełnoprawny członek zbiorowości, ceniony za swe szczególne własności, a jednocześnie pozbawiony zewnętrznego wsparcia. Autor Filozofii pieniadza pisał, że człowiek taki „,...] nie jest skrępowany zobowiązaniami, które mogłyby wpłynąć na jego sposób postrzegania, rozumienia i dokonywania wyboru”. Dzięki temu zaś „,[...] ma większą swobodę praktyczną i teoretyczną, obserwuje sytuację bardziej bezstronnie, ocenia ją, stosując bardziej ogólne i obiektywne kryteria, w swym działaniu pozostaje nieskrępowany przyzwyczajeniem, nabożnym szacunkiem ani tradycją" (tamże: 302). Simmel, który przez całe swoje życie posiadał w środowisku akademickim status „obcego", z jednej strony borykał się ze związanym z nim problemem odrzucenia, z drugiej zaś miał dzięki niemu przestrzeń do dokonywania wyjątkowo innowacyjnych rozpoznań. W niniejszym tekście unaoczniłem to, że do dzisiaj stanowią one wyjątkowo ważną inspirację dla intelektualistów. Ponad stulecie od swej śmierci jest nam on w dużo większej mierze „bliski” niż „obcy”.

Bibliografia:

/// Bachmann-Medick D. 2012. Cultural Turns. Nowe kierunki w naukach o kulturze, tłum. K. Krzemieniowa, Oficyna Naukowa.

/// Bauman Z. 1995. Freud, Kafka, Simmel. Próba hermenentyki socjologicznej, [w:] Pojednanie tożsamości z różnica?, red. E. Rewers, Wydawnictwo Fundacji Humaniora, s. 19-44.

/// Bauman Z. 2005. Raz̧em, osobno, tłum. T. Kunz, Wydawnictwo Literackie.

/// Bauman Z. 2006. Płynna nowoczesność, tłum. T. Kunz, Wydawnictwo Literackie.

/// Bauman Z. 2012. Kultura jako praxis, tłum. J. Konieczny, Wydawnictwo Naukowe PWN.

/// Bauman Z., Kubicki R., Zeidler-Janiszewska A. 2009. Żcie w kontekstach. Rozmowy o tym, co za nami i o tym, co przed nami, Wydawnictwa Akademickie i Profesjonalne. 
/// Bourdieu P. 2007. Reguly sztuki. Geneza i struktura pola literackiego, red. M. Sugiera, tłum. A. Zawadzki, Universitas.

/// Brzeziński D. 2019. Myśl spoteczna Georga Simmla w perspektywie wspótczesnej teorii i socjologii kultury, „Przegląd Socjologiczny”, nr 1, s. 119-136.

/// Cieśla S. 1993. Georg Simmel i podstawy jego socjologii, Redakcja Wydawnictw KUL.

/// Coser L. 1958. Georg Simmel's Style of Work: A Contribution to the Sociology of the Sociologist, „Americal Journal of Sociology”, nr 6, s. 635-641.

/// De La Fuente E. 2016. A Qualitative Theory of Culture: Georg Simmel and Cultural Sociology, [w:] The Sage Handbook of Cultural Sociology, red. D. Inglis, A.-M. Almila, Sage, s. 78-90.

/// Etzkorn K.P. 1964. Georg Simmel and the Sociology of Music, „Social Forces", nr 43(1), s. 101-107.

/// Frisby D. 1992. Simmel and Since. Essays on Georg Simmel's Social Theory, Routledge.

/// Frisby D., Feathertone M., red. 1997. Simmel on Culture. Selected Writings, Sage.

/// Frischeisen-Köhler M. 1919. Georg Simmel, „Kant Studien”, nr 24, s. $1-52$.

/// Gadacz T. 2005. Simmel i filozofia ஷ̇ycia, „Sztuka i Filozofia”, nr 27, s. $5-30$.

/// Gassen K., Landmann M., red. 1958. Buch des Dankes an Georg Simmel. Briefe, Erinnerungen, Bibliographie, Dunker \& Humblot.

/// Geertz C. 1996. O gatunkach zmaconych (Nowe konfiguracje myśli spotec₹nej), tłum. Z. Lapiński, [w:] Postmoderniżm. Antologia przekładón, red. R. Nycz, Wydawnictwo Baran i Suszczyński, s. 214-235.

/// Harrington A., Kemple T.M. 2012. Georg Simmel's „Sociological Metaphysics”: Money, Sociality, and Precarious Life, „Theory, Culture and Society”, nr 7-8, s. 7-25.

/// Hoffmann B. 2019. Georg Simmel i flakonik perfum, „Przegląd Socjologiczny", nr 1, s. 137-156.

/// Jabłońska B. 2014. Socjologia mu₹yki, Wydawnictwo Naukowe Scholar. 
/// Jacobson R. 1989. W posqukiwanin istoty jezyka: wybórpism, wybór, redakcja i wstęp M.R. Mayenowa, t. I-II, Państwowy Instytut Wydawniczy.

/// Jacoby R. 2005. Picture Imperfect. Utopian Thought for an Anti-Utopian Age, Columbia University Press.

/// Lepenies W. 1997. Trzy kultury. Socjologia miedzy literatura a nauka, thum. K. Krzemień-Ojak, Wydawnictwo Poznańskie.

/// Karalus A. 2018. Georg Simmel's "The Pbilosophy of Money" and the Moderniqation Paradigm, „Polish Sociological Review”, nr 4, s. 429-455.

/// Kuźniar B. 2018. Simmel and the Posthuman: Money as the Good of Bad Infinity, „Polish Sociological Review”, nr 4, s. 447-461.

/// Levine D., red. 1971. Georg Simmel on Individuality and Social Forms, University of Chicago Press.

/// Levitas R. 2001. For Utopia: The (Limits of the) Utopian Function in Late Capitalist Society, [w:] The Philosophy of Utopia, red. B. Goodwin, Routledge, s. $25-43$.

/// Magala S. 1980. Simmel, Wiedza Powszechna.

/// Markowska B. 2018. Homo Libidinous and the Economy of Desire: Rereading Simmel's „The Philosophy of Money” after Freud, „Polish Sociological Review”, nr 4, s. 485-498.

/// Motak D. 2013. Między transcendencja a immanencja. Religia w myśli Georga Simmla, Wydawnictwo LIBRON.

/// Nycz R. 2017. Kultura jako crasownik. Sondowanie nowej bumanistyki, Wydawnictwo IBL PAN.

/// Palmer J., Brzeziński D., Campbell T. 2020. Sixty Three Years of Thinking Sociologically: Compiling the Bibliography of Zygmunt Bauman, „Thesis Eleven”, nr 1, s. 118-133.

/// Sargent L.T. 2006. In Defense of Utopia, „Diogenes”, nr 1, s. 11-17.

/// Schilling C. 2002. The Two Traditions in the Sociology of Emotions, „The Sociological Review", nr 50(2), s. 10-32.

/// Simmel G. 1882. Psychologische und ethnologische Studien über Musik, „Zeitschrift für Völkerpsychologie und Sprachwissenschaft", nr 13, s. 261-305.

/// Simmel G. 1913. Goethe, Klinkhardt. 
/// Simmel G. 1916. Rembrandt, Wolff.

/// Simmel G. 1917. Grundfragen der Soziologie, Göschen.

/// Simmel G. 1958. Anfang einer unvollendeten Selbstdarstellung, [w:] Buch des Dankes an Georg Simmel. Briefe, Erinnerungen, Bibliographie, red. K. Gassen, K.M. Landmann, Dunker \& Humblot.

/// Simmel G. 1997. Filozofia pieniadza, tłum. A. Przyłębski, Wydawnictwo Fundacji Humaniora.

/// Simmel G. 1998. Momentbilder sub specie aeternitatis. Philosophische Miniaturen, Heidelberg.

/// Simmel G. 2005a. Problem portretu, tłum. K. Lukasiewicz, „Sztuka i Filozofia", nr 27, s. 89-97.

/// Simmel G. 2005b. Rembrandt: sækic ₹ filozofii sætuki, tłum. W. Zahaczewski, „Sztuka i Filozofia”, nr 27, s. 98-128.

/// Simmel G. 2005c. Socjologia, tłum. M. Lukasiewicz, Wydawnictwo Naukowe PWN.

/// Simmel G. 2006. Most i drawi, tłum. M. Łukasiewicz, Oficyna Naukowa.

/// Simmel G. 2007a. Filozofia kultury: wybór esejón, tłum. W. Kunicki, Wydawnictwo Uniwersytetu Jagiellońskiego.

/// Simmel G. 2007b. Filozofia ¿̇ycia: cztery rozdzialy metafizyczne, tłum. M. Tokarzewska, Wydawnictwo IFiS PAN.

/// Symons M. 1994. Simmel's gastronomic sociology: An overlooked essay, „Food and Foodways", nr 5(4), s. 333-351.

/// Szacki J. 2003. Historia myśli socjologicznej. Wydanie nowe, Wydawnictwo Naukowe PWN.

/// Sztompka P., Bogunia-Borowska M., red. 2008. Socjologia codżienności, Znak.

/// Swartz D. 1997. Culture \& Power. The Sociology of Pierre Bourdieu, The University of Chicago Press.

/// Tokarzewska M. 2005. Narracja i mgnienie oka. O miniaturze filozoficznej Georga Simmla „Żaden Poeta”, „Sztuka i Filozofia”, nr 27, s. 131-146. 
/// Tokarzewska M. 2008. Georg Simmel o tajemnicy, „Studia Socjologiczne”, nr 2, s. 65-90.

/// Vanini P., Waskul D., Gottschalk S. 2011. The Senses in Self, Society, and Culture: A Sociology of the Senses, Routledge.

\section{/// Abstrakt}

Georg Simmel jest znakomitym przykładem „intelektualisty totalnego”, to jest - zgodnie z rozumieniem Pierre’a Bourdieu - myśliciela swobodnie przekraczającego granice między dziedzinami i dyscyplinami nauki czy też dokonującego transferu wiedzy między różnymi polami twórczej aktywności. Autor Filozofii pieniadza swobodnie łączył socjologię, filozofię, ekonomię, naukę o sztuce, refleksje natury literaturoznawczej etc. Pozwalało mu to na dokonywanie wielu wyjątkowo innowacyjnych rozpoznań - w tym na zainicjowanie nowych ścieżek myślowych - ale też spotkało się z krytyką ze strony mu współczesnych. Pozostawanie „ponad granicami" dotyczyło nie tylko sposobu, w jaki prowadził swoje analizy, ale także języka, za pomocą którego je przedstawiał. Ulubioną formą wypowiedzi Simmla był esej, w którym stosował środki retoryczne właściwe językowi literackiemu. Tak sam charakter jego refleksji, jak i wyjątkowo innowacyjny sposób, w jaki je przedstawiał, przyczyniły się do tego, że do dziś pozostaje on intelektualistą, na którego twórczość powołują się przedstawiciele bardzo różnych dyscyplin społecznych i humanistycznych. W artykule zgłębiam ów fenomen, koncentrując się zarówno na samej myśli Simmla, jak i współczesnych sposobach jej odczytania.

Słowa kluczowe:

Georg Simmel, intelektualiści totalni, interdyscyplinarność, dyskurs, obcość

\section{/// Abstract}

Thinking beyond Borders: Interdisciplinarity and the Innovativeness of Georg Simmel's Work

Georg Simmel is an excellent example of a "total intellectual", in other words, according to Pierre Bourdieu, a thinker who crosses the boundaries between disciplines and fields of scholarship, or who transfers knowledge 
between various fields of activity. Simmel freely combined sociology, philosophy, economics, fine art studies, literary studies, and so forth. On the one hand, this attitude lay the foundation for his exceptionally innovative analyses and led to the establishment of new paths of thought. On the other hand, it was met with strong criticism from contemporary intellectuals. Simmel thought "beyond borders" not only in conducting his analyses but also in choosing the language in which to present them. His preferred form of expression was an essay in which he would use many rhetorical devices specific to literary language. Both the nature of Simmel's analyses and the innovative way in which he presented them contributed to the fact that his works have continued to this day to inspire intellectuals in many different fields of the social sciences and humanities. In this article, the author explores the phenomenon, focusing on both Simmel's thinking "beyond borders" and contemporary ways of interpreting those ideas.

Keywords:

Georg Simmel, total intellectuals, interdisciplinarity, discourse, foreignness

/// Dariusz Brzeziński - doktor nauk społecznych, adiunkt w Zakładzie Socjologii Teoretycznej IFiS PAN. Jego zainteresowania naukowe obejmuja głównie współczesną myśl społeczna, a także socjologię, antropologię i teorię kultury. W tych obszarach prowadzi także wykłady i zajęcia dydaktyczne na Uniwersytecie Jagiellońskim. Opublikował dwie monografie autorskie: Twórczość Zygmunta Baumana we wspótczesnych teoriach kultury (2017, angielskie tłumaczenie ukaże się w 2021 roku), Myślenie utopijne w twórczości Zygmunta Baumana (2015). Jest również autorem artykułów, które ukazały się między innymi w: „European Journal of Social Theory”, „Thesis Eleven”, „Polish Sociological Review”, „Studiach Socjologicznych”, „Przeglądzie Socjologicznym”, „Kulturze i Społeczeństwie”. W latach 2018-2023 Visiting Research Fellow w School of Sociology and Social Policy na University of Leeds.

ORCID: https://orcid.org/0000-0002-9978-9333

E-mail: dariusz.brzezinski@ifispan.waw.pl 